September 2003 - NREL/TP-500-34648

\title{
Modeling the Feasibility of Using Fuel Cells and Hydrogen Internal Combustion Engines in Remote Renewable Energy Systems
}

J. Cotrell

W. Pratt, Research Associate

Laboratory Science Teacher Professional Development Program

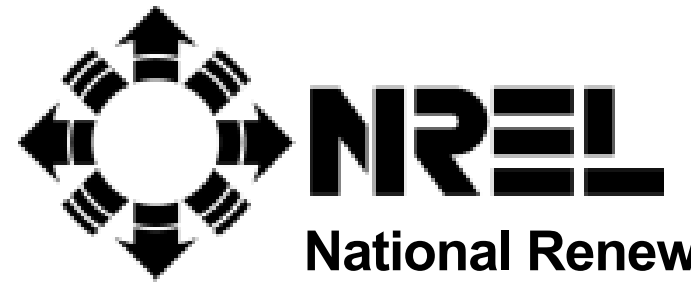

1617 Cole Boulevard

Golden, Colorado 80401-3393

NREL is a U.S. Department of Energy Laboratory

Operated by Midwest Research Institute $\bullet$ Battelle $\bullet$ Bechtel

Contract No. DE-AC36-99-G010337 


\section{Modeling the Feasibility of Using Fuel Cells and Hydrogen Internal Combustion Engines in Remote Renewable Energy Systems}

J. Cotrell

W. Pratt, Research Associate Laboratory Science Teacher Professional Development Program

Prepared under Task No. WER3 3250

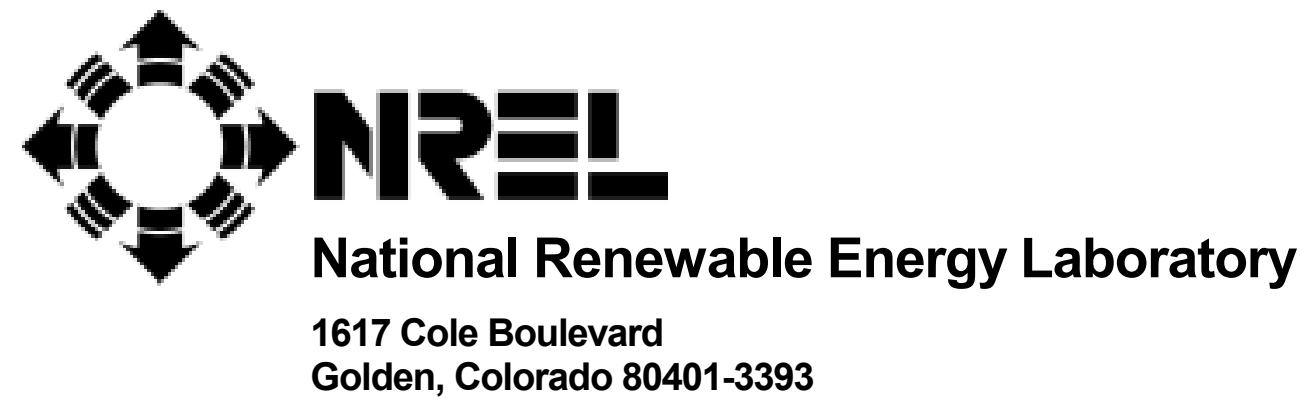

NREL is a U.S. Department of Energy Laboratory Operated by Midwest Research Institute • Battelle • Bechtel Contract No. DE-AC36-99-G010337 


\section{NOTICE}

This report was prepared as an account of work sponsored by an agency of the United States government. Neither the United States government nor any agency thereof, nor any of their employees, makes any warranty, express or implied, or assumes any legal liability or responsibility for the accuracy, completeness, or usefulness of any information, apparatus, product, or process disclosed, or represents that its use would not infringe privately owned rights. Reference herein to any specific commercial product, process, or service by trade name, trademark, manufacturer, or otherwise does not necessarily constitute or imply its endorsement, recommendation, or favoring by the United States government or any agency thereof. The views and opinions of authors expressed herein do not necessarily state or reflect those of the United States government or any agency thereof.

Available electronically at http://www.osti.gov/bridge

Available for a processing fee to U.S. Department of Energy and its contractors, in paper, from:

U.S. Department of Energy

Office of Scientific and Technical Information

P.O. Box 62

Oak Ridge, TN 37831-0062

phone: 865.576 .8401

fax: 865.576.5728

email: reports@adonis.osti.gov

Available for sale to the public, in paper, from:

U.S. Department of Commerce

National Technical Information Service

5285 Port Royal Road

Springfield, VA 22161

phone: 800.553.6847

fax: 703.605.6900

email: orders@ntis.fedworld.gov

online ordering: http://www.ntis.gov/ordering.htm 


\section{Table of Contents}

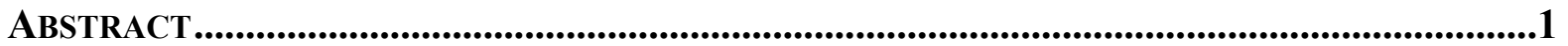

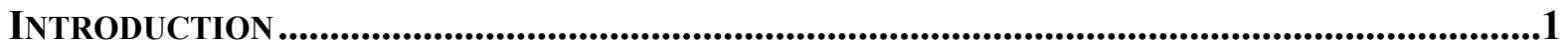

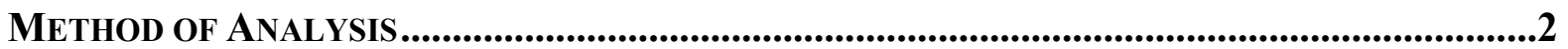

RADIO REPEATER ANALYSIS ...............................................................................................2

SYSTEM DESCRIPTION ..........................................................................................

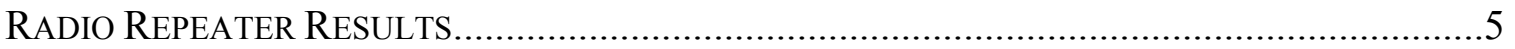

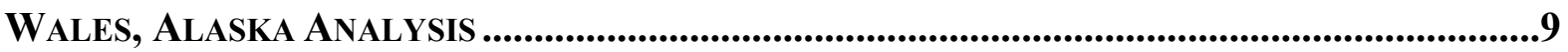

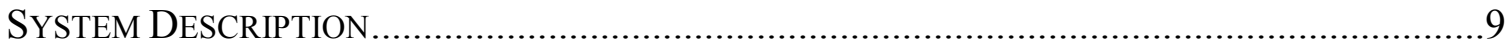

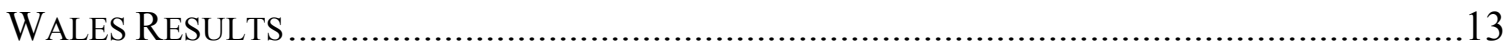

CONCLUSIONS....................................................................................................................16

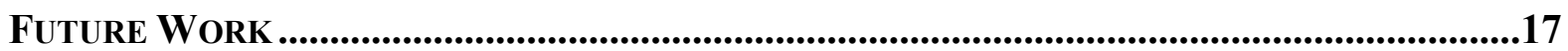

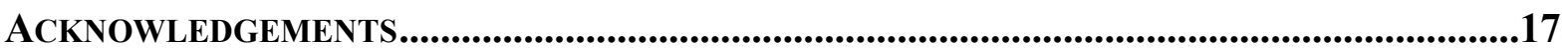

REFERENCES....................................................................................................................................17

\section{Table of Figures}

FIGURE 1: SCHEMATIC OF THE RADIO REPEATER STATION. ............................................................

FIGURE 2: OPTIMAL SYSTEM TYPE (WITH COE SUPERIMPOSED) AS A FUNCTION OF ELECTROLYZER AND

FUEL CELL CAPITAL COSTS AND MEAN ANNUAL WIND SPEED. ................................... 7

FIGURE 3: OPTIMAL SYSTEM TYPE (WITH NUMBER OF BATTERIES SUPERIMPOSED) AS A FUNCTION OF

ELECTROLYZER AND FUEL CELL CAPITAL COSTS AND MEAN ANNUAL WIND SPEED. ............9

FIGURE 4: SCHEMATIC OF THE LOW-HYDROGEN-PENETRATION SYSTEM IN WALES (HYDROGEN

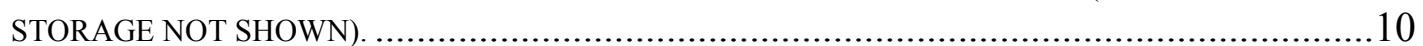

FIGURE 5: TOTAL CAPITAL COSTS FOR EACH SYSTEM RELATIVE TO THE DIESEL-WIND-BATTERY

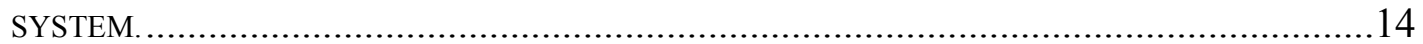

FIGURE 6: COST OF ENERGY FOR EACH SYSTEM RELATIVE TO THE DIESEL-WIND BATTERY SYSTEM. ..15

FIGURE 7: TOTAL ANNUALIZED COST FOR THE WIND-DIESEL-FUEL CELL SYSTEM............................15

FIGURE 8: OPTIMAL SYSTEM TYPE AS A FUNCTION OF FUEL CELL CAPITAL COSTS AND DIESEL COST

FOR WALES LOW-PENETRATION SYSTEMS. ............................................................. 16

\section{Table of Tables}

TABLE 1: OPTIMIZATION SEARCH SPACE USED FOR THE RADIO REPEATER STUDY ............................6

TABLE 2: LEAST-COST SOLUTION IN EACH CATEGORY FOR THE RADIO REPEATER STUDY (3.49 M/S MEAN WIND SPEED; ELECTROLYZER AND FUEL CELL CAPITAL COST MULTIPLIERS $=1)$.......6

TABLE 3: LEAST-COST SOLUTION IN EACH CATEGORY FOR THE RADIO REPEATER STUDY USING LEAD ACID BATTERIES (3.49 M/S MEAN WIND SPEED; ELECTROLYZER AND FUEL CELL CAPITAL

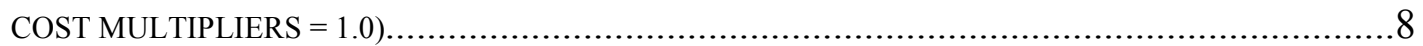

TABLE 4: OPTIMIZATION SEARCH SPACE USED FOR THE WALES LOW-HYDROGEN PENETRATION

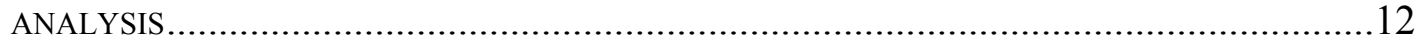

TABLE 5: LEAST-COST SOLUTIONS IN EACH CATEGORY FOR THE WALES ANALYSIS (ASSUMING \$.35/L DIESEL WITH ELECTROLYZER AND FUEL CELL CAPITAL MULTIPLIERS $=1) \quad \ldots \ldots \ldots \ldots \ldots \ldots \ldots \ldots . . . . . . . . .14$ 


\section{Abstract}

Recent advances in hydrogen fuel cell and internal combustion engine technologies have enabled new energy options for supplying electrical power in remote, off-grid areas. The objective of this investigation is to determine under which conditions wind turbines and PV systems can feasibly power electrolyzers to generate and store hydrogen for remote power generation using fuel cells and internal combustion engines. In this study, the optimization software HOMER is used to analyze a small $356-\mathrm{W}$ radio repeater station and a $148-\mathrm{kW}$ village power system. This study concludes that fuel cell systems appear competitive today at the radio repeater station and appear competitive in the village system if fuel cell prices are reduced to $40 \%$ of their current capital cost.

\section{Introduction}

The use of renewable energy systems to supply electrical power in remote, off-grid areas is fairly well established throughout the world. Small- and medium-scale applications in the United States include sites such as construction sites, telecommunication stations, highway rest areas, single homes, science research stations, National Park facilities, and small villages.

Depending on the resources available, such systems typically rely on photovoltaic (PV) modules and/or wind turbines as the primary renewable power source. These systems usually also employ batteries for short-term back-up power. The technology advancements in hydrogen electrolyzers, fuel cells, internal combustion engines, and storage in the past five years have made the storage of excess renewable energy as hydrogen an intriguing alternative to established back-up power systems. Assuming that reliable, low-maintenance systems can be designed, they are expected to first become competitive in remote locations in which electricity is expensive because there are no links to power grids serving the main urban areas. This investigation examines the conditions under which these systems might be economically competitive in these areas.

For small-scale systems, such as for telecommunication stations, wind turbines or PV systems can often provide all the energy at an acceptable cost. For medium-scale systems, such as small villages, the renewable systems may only contribute a fraction of the energy, with the primary load being served by a diesel generator. The cost of energy is often high in these regions because diesel is a relatively expensive means of producing electricity. For example, there are more than 200 rural villages in Alaska that are not linked to the power grids serving the main urban areas. The majority of these villages are served by diesel-driven generators. Because of the extreme remoteness of most of these communities and the lack of roads, the delivered cost of diesel fuel is high, ranging from $\$ 1.00$ to $\$ 3.00$ per gallon ( $\$ .26$ to $\$ .79$ per liter). In addition, the high operations and maintenance (O\&M) costs of diesel-generating stations contribute to electric generation costs that average nearly $\$ 0.40 / \mathrm{kWh}$ and can be as high as $\$ 1.00 / \mathrm{kWh}^{1}$.

This study examines the technical feasibility of two autonomous renewable energy systems at two locations. The first location is a $350-\mathrm{W}$-rated, PV/battery-powered radio repeater system located east of Prineville, Oregon ( $\left.44^{\circ} 20^{\prime} \mathrm{N}, 120^{\circ} 50^{\prime} \mathrm{W}\right)$. The second location is Wales, Alaska. Wales uses two 50-kW wind turbines and a battery bank to supplement diesel generators. Both systems are examined to determine 1) whether hydrogen systems are competitive today, 2) at what cost hydrogen systems will become economically competitive, and 3) when hydrogen systems are likely to become competitive. 


\section{Method of Analysis}

Studying the feasibility of adding hydrogen systems to the locations considered requires optimizing the size and number of the system components. Many different size possibilities and hardware configurations must be determined. For example, the size of the PV system, electrolyzer, hydrogen storage tank, fuel cell, and internal combustion engine (ICE) must be determined to ensure that the system is able to meet the required load at the lowest possible cost.

The optimization software used for this effort is version 2.0 of the Hybrid Optimization Model for Electric Renewables (HOMER), which is freely available from the National Renewable Energy Laboratory (NREL). HOMER performs comparative economic analyses on distributed generation power systems. Inputs to HOMER include load data, renewable resource data, system component specifications and costs, and various optimization parameters (e.g., number of components, percentage of unmet load, etc.). HOMER will perform an hourly simulation of every possible combination of components entered and rank the systems according to user-specified criteria, such as cost of energy (COE) or capital costs. Furthermore, HOMER can perform "sensitivity analyses" in which the values of certain parameters (e.g., fuel cell cost) are varied to determine their impact on the COE.

To obtain the input data for HOMER, hydrogen component information was collected from research literature and manufacturers to obtain present and future estimates of hydrogen system costs and efficiencies. Also collected are the load and resource time series data and information necessary to model the systems.

\section{Radio Repeater Analysis}

\section{System Description}

The radio repeater station is a $356-\mathrm{W}, 12-\mathrm{V}, \mathrm{PV} /$ battery-powered system located east of Prineville, Oregon $\left(44^{\circ} 20^{\prime} \mathrm{N}, 120^{\circ} 50^{\prime} \mathrm{W}\right)$. HOMER was used to determine whether using a fuel cell or wind turbine with the system is economically competitive. FIGURE 1 depicts the system with a wind turbine, electrolyzer, hydrogen storage, and fuel cell added to the system. The assumptions and system properties are described in detail below.

\section{Operating Principle}

The theory of operation is to use the PV system or wind turbine to directly meet the load whenever possible to minimize the losses in the battery and fuel cell. When excess wind or PV energy is available, power is supplied first to the batteries, then to an electrolyzer, which consumes water to generate hydrogen for storage. The batteries or the fuel cell is then used to meet the load when the wind or solar energy is insufficient. HOMER decides whether to use energy from the battery, fuel cell, or both based on the replacement cost and O\&M of the devices. Because this analysis neglects O\&M and because the fuel cell is not replaced during its lifetime, HOMER uses the full extent of the fuel cell capacity for this system before using the batteries. 


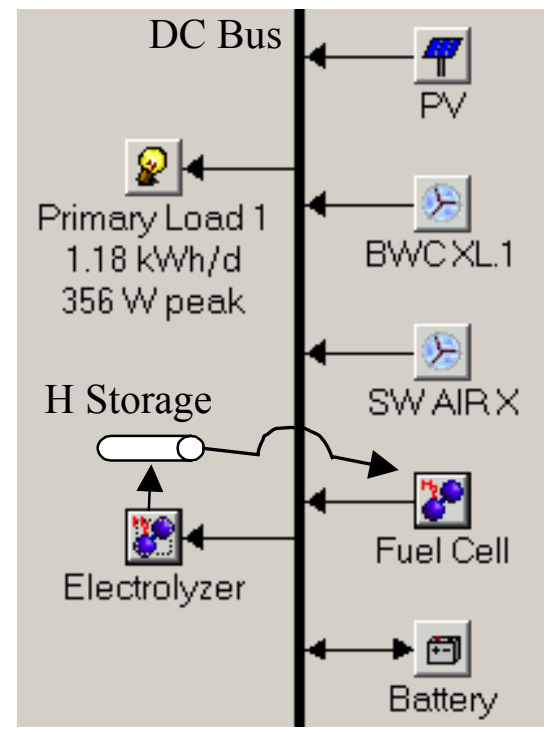

FIGURE 1: SCHEMATIC OF THE RADIO REPEATER STATION.

\section{Load}

Load data were obtained from system specifications ${ }^{2}$. The station has an annual average DC load of $1.182 \mathrm{kWh} / \mathrm{d}$. The summer load average (April through September) is $1.716 \mathrm{kWh} / \mathrm{d}$, and the winter average (October through March) is $0.652 \mathrm{kWh} / \mathrm{d}$. The daily load profile was not available, so HOMER was used to estimate load profile using the duty cycles available in the specifications. Daily and hourly noise values of $10 \%$ were employed in HOMER, resulting in a maximum load of $356 \mathrm{~W}$.

HOMER allows input of the operating reserve for the system. The operating reserve is the surplus generation capacity used to compensate for rapid fluctuations of load, sunshine, or wind resource. The amount of operating reserve is specified as a percentage of hourly load and renewable resources. For the results reported here, the operating reserve was required to be $10 \%$ of the hourly load, plus $50 \%$ of the wind turbine power output and $25 \%$ of the PV power output.

\section{Resources}

Solar radiation and clearness data for this site were from nearby Pendleton, Oregon $\left(45^{\circ} 40^{\prime} \mathrm{N}\right)$. The data were derived from the NREL TMY2 (Typical Metrological Year) database. The annual average global radiation is $4.15 \mathrm{kWh} / \mathrm{m}^{2} /$ day, with an annual average clearness index of 0.573 . Hourly wind resource data for the site were unavailable, but it is located in a Class 1 wind regime, so data from nearby Pendleton, Oregon (also a Class 1 regime) were again used ${ }^{3}$. The average wind speed is $3.5 \mathrm{~m} / \mathrm{s}$ (Weibull-k value $=1.67$ ).

\section{Operations and Maintenance}

In this analysis, the operations and maintenance costs are neglected even though they are likely significant. Data for the fuel cell and electrolyzer maintenance costs could not be found. In addition, the O\&M costs are difficult to divide among components in such a small system. Instead of attempting this task, we assumed that the system is designed to run in a maintenancefree fashion. 


\section{PV Modules}

This scenario was modeled with PV panels fixed at a slope of $44.2^{\circ}$. The installed cost of a $1-\mathrm{kW}$ (peak) PV array ranges between $\$ 6.00 / \mathrm{W}$ and $\$ 10.00 / \mathrm{W}^{4}$. The baseline capital cost of the PV in this study was $\$ 8.00 / \mathrm{W}$. Lifetimes were assumed to be 20 years.

\section{Wind Turbines}

Although the radio repeater station does not use wind turbines, this study considers the feasibility of adding wind turbines to the system. Furthermore, the wind speed is varied to investigate the hypothetical case of a region with faster winds.

Two wind turbines were considered in this study: a Bergey XL1 1-kW turbine and a Southwest Windpower AIR-X rated at 400W. The cost of the Bergey DC turbine and 9-m tower $(\$ 2,430)$ was obtained from Bergey's Web site. The cost of the AIR-X with a 7.6-m tower (\$849) was found on a supplier Web site. Transportation and installation costs were estimated to be $\$ 400$, for installed total costs of $\$ 2,830$ and $\$ 1,249$, respectively. It was assumed that the machines would last 20 years.

\section{Electrolyzers}

Proton exchange membrane (PEM) electrolyzers from Proton Energy Inc. were used to obtain a cost estimate of a stand-alone ("hydrogen by wire") electrolyzer. The system used to obtain a $\$ / \mathrm{kW}$ cost for electrolyzers is a HOGEN $406-\mathrm{kW}$ electrolyzer. It includes the PEM stack, power electronics, and control system. The current production cost of the HOGEN 40 is approximately $\$ 16,000$ or $\$ 2,700 / \mathrm{kW}$. Projected costs are expected to be approximately $\$ 700 / \mathrm{kW}$ within 10 years ${ }^{5}$. Cost reductions are expected to stem from improvements in the PEM stack, power electronics, control system, and manufacturing improvements such as replacing fittings with welded tube assemblies. These costs assume production of 500 units per year. A profit margin of $30 \%$ was added to these costs to estimate the purchase price of the electrolyzer. The total cost is then $\$ 3,500 / \mathrm{kW}$. The installation cost was deemed to be negligible because the HOGEN 40 is a self-contained unit. The efficiency of electrolyzers using the higher heating value is estimated to be between $70 \%$ and $85 \%{ }^{6}$. A constant value of $83 \%$ ( $70 \%$ using the lower heating value) was used for this study.

Feed water and cooling water are required for the electrolyzer. To avoid contaminating the electrolyzer, feed water should be purified and deionized. Small, remote systems (e.g., telecomm) may use a storage tank; larger systems (e.g., rest areas, homes) can draw from existing water lines. Water treatment systems need regular maintenance such as filter cartridge replacement. The cost of a filter cartridge system and O\&M for the radio repeater station was neglected as the water use in the electrolyzer is small. The PV-fuel cell-battery system uses approximately 4 gallons per year, and the system that consumes the most water is the PV-fuel cell system, which uses approximately 35 gallons per year. In addition, a water recycling system between the fuel cell and electrolyzer could also reduce the amount of water needed if necessary.

Conventional electrolyzers produce hydrogen at low pressure (100-200 psi). Compressors are used to elevate the pressure for gas storage. However, 2,500-3,000 psi production pressures have been demonstrated recently at Proton energy and are expected to be in production in the very near future; targets are upward of 6,000 psi. In addition, a relatively new U.S. company, Avalence, has demonstrated an electrolyzer technology that can produce hydrogen at pressures up to $10,000 \mathrm{psi}$. Such technologies will likely eliminate the need for compressors. Accordingly, this study assumed that a compressor was not required. 


\section{Hydrogen Storage}

Hydrogen can be stored several ways. Small amounts of hydrogen are most commonly stored as a compressed gas or as a metal hydride. Compressed gas storage is currently the most costeffective for small-scale system tanks, so it is used for this study; small-quantity prices are around $\$ 1,320 / \mathrm{kg}^{7}$ with long-term targets of $\$ 165 / \mathrm{kg}^{8}$. These cost reductions of small-scale storage are likely to result from automotive research into compressed hydrogen storage.

\section{Fuel Cells}

A PEM fuel cell was assumed for this study. The cost of fuel cells varies widely depending on scale, power electronics requirements, and reformer requirements. A survey performed for this study identified three fuel cells that currently sell for between $\$ 3,000 / \mathrm{kW}$ and $\$ 6,000 / \mathrm{kW}^{9,10,11}$. One high-temperature membrane technology currently being pursued is expected to have a membrane life of greater than 20,000 hours and an overall installed fuel cell system cost of less than $\$ 1,500 / \mathrm{kW}$ for initial commercialization (by 2008) and ultimately $\$ 400 / \mathrm{kW}$ for large markets (by 2010). ${ }^{12}$ Stationary fuel cells are targeted to last 30,000 to 40,000 operating hours, during which the membrane will likely have to be replaced one or more times. This study assumed the fuel cell would last 30,000 hours.

The baseline capital cost used for this study is $\$ 5,000 / \mathrm{kW}$ for the radio repeater (because of its very small scale). The efficiencies of PEM fuel cells running on pure hydrogen are roughly $40 \%$ to $50 \%{ }^{13}$ (lower heating value) at rated power with slightly higher values at partial load. The electrical efficiency used for this study was held constant at $45 \%$ to compensate for parasitic losses, which occur at partial load.

\section{Batteries}

The radio repeater station uses four GNB 3-75A21 deep-cycle batteries with two in parallel for a nominal voltage of $12 \mathrm{~V}$. Each $6 \mathrm{~V}$ battery has a rated capacity of 930Ah. The average cost of the battery system is $\$ 930$ per battery ${ }^{14}$, or $\$ 166 / \mathrm{kWh}$. Initial studies were performed using these batteries. However, it was determined that these relatively large batteries were too large to permit sufficient resolution of the battery search space. Therefore, the simulations were repeated using the smaller NiCad battery cells used in the Wales system. These batteries are 1.2V Saft SPH130 NiCad cells with $130 \mathrm{Ah}$ capacities. The average cost of each cell is $\$ 218$, or $\$ 1,400 / \mathrm{kWh}$. Although it is probably not technically feasible, this study assumed it was possible to use any number of batteries.

\section{Radio Repeater Results}

In HOMER, a solution is a particular hybrid system configuration. As HOMER searches for the optimal hybrid system design, it typically evaluates hundreds or thousands of solutions. HOMER performs an hourly time series simulation of every solution and eliminates solutions that cannot meet the required load. For this case, HOMER examined the 229,635 solutions possible by combining components listed in TABLE 1.

Careful attention was paid to ensure that the search space is adequately broad and has sufficient resolution to ensure optimal configurations. The gray highlighted cells indicate component sizes that result in selected solutions. The cells without color (which indicate these components were not selected) are an indication that the search space is sufficiently broad (except for the wind turbines), and in some cases (such as for the fuel cell), they indicate sufficient resolution.

Sensitivity studies on the fuel cell and electrolyzer cost and on the wind speed were performed at 60 points in the final analysis. Each point required that HOMER repeat all 229,635 simulations, 
for a total of nearly 14 million simulations. On a modern $2-\mathrm{GHz} \mathrm{PC}$, this took 76 hours to complete.

TABLE 1: OPTIMIZATION SEARCH SPACE USED FOR THE RADIO REPEATER STUDY

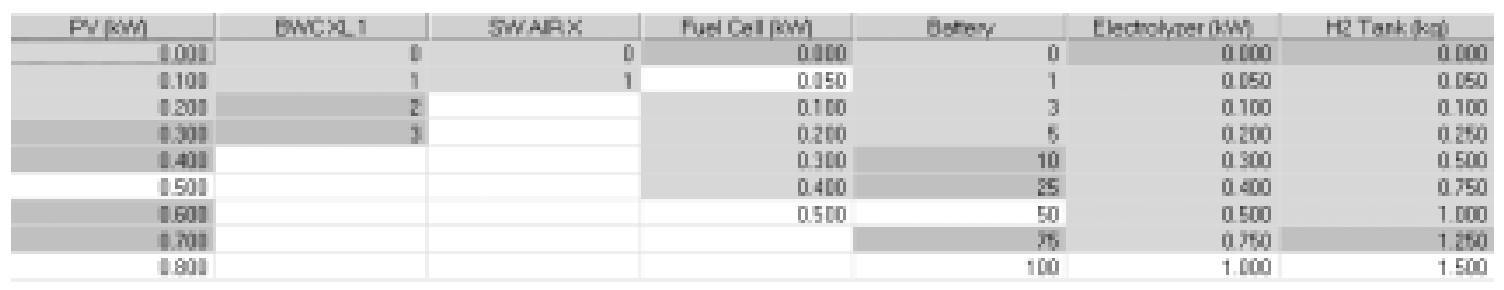

HOMER categorizes the viable solutions according to the types of components they contain. The simulation resulted in six categories, which are listed in TABLE 2 in order of increasing cost of energy. Each row in TABLE 2 contains the least-cost solution for that category.

TABLE 2: LEAST-COST SOLUTION IN EACH CATEGORY FOR THE RADIO REPEATER STUDY (3.49

M/S MEAN WIND SPEED; ELECTROLYZER AND FUEL CELL CAPITAL COST MULTIPLIERS = 1)

\begin{tabular}{|c|c|c|c|c|c|c|c|c|c|c|}
\hline \multirow[b]{2}{*}{ Category } & \multicolumn{6}{|c|}{ Configuration } & \multicolumn{4}{|c|}{ Performance } \\
\hline & $\begin{array}{l}\text { PV } \\
\text { kW }\end{array}$ & $\begin{array}{c}\text { Turbines } \\
\text { kW }\end{array}$ & $\begin{array}{c}\text { Fuel Cell } \\
\text { kW }\end{array}$ & $\begin{array}{c}\text { Batts } \\
\text { Ea. }\end{array}$ & $\begin{array}{c}\text { Electrolyzer } \\
\text { kW }\end{array}$ & $\begin{array}{c}\text { H Store } \\
\text { kg } \\
\end{array}$ & & $\begin{array}{l}\text { tal Cap. } \\
\$\end{array}$ & $\begin{array}{c}\text { COE } \\
\$ / k W h \\
\end{array}$ & $\begin{array}{l}\text { FC } \\
\text { hrs }\end{array}$ \\
\hline PV WT FC Bat & 0.20 & 1.0 & 0.2 & 3 & 0.30 & 1.0 & $\$$ & 8,454 & 1.70 & 1,026 \\
\hline PV FC Bat & 0.60 & - & 0.1 & 10 & 0.30 & 0.3 & $\$$ & 8,860 & 1.87 & 1,058 \\
\hline WT FC Bat & - & 2.0 & 0.3 & 3 & 0.40 & 1.3 & $\$$ & 10,864 & 2.18 & 1,101 \\
\hline PV WT Bat & 0.40 & 0.4 & - & 25 & - & - & $\$$ & 9,899 & 2.23 & - \\
\hline PV WT FC & 0.30 & 1.0 & 0.4 & - & 0.30 & 0.8 & $\$$ & 9,270 & 2.26 & 4,063 \\
\hline PV Bat & 0.60 & - & - & 25 & - & - & $\$$ & 10,250 & 2.30 & - \\
\hline PV FC & 0.70 & - & 0.4 & - & 0.50 & 0.8 & $\$$ & 10,340 & 2.62 & 5,006 \\
\hline WT FC & - & 2.0 & 0.4 & - & 0.50 & 1.3 & $\$$ & 11,060 & 2.81 & 5,347 \\
\hline
\end{tabular}

Assuming a wind speed of $3.49 \mathrm{~m} / \mathrm{s}$ and present fuel cell and electrolyzer costs, the PV-wind-fuel cell-battery configuration has the lowest COE. This result demonstrates how batteries and hydrogen systems are complementary. If the fuel cell is removed from this configuration (as in the PV-wind-battery configuration), the optimum number of batteries increases nearly eightfold from 3 to 25 batteries. This dramatic increase occurs because the hydrogen system can store energy relatively cheaply compared to the batteries. The capital cost of the batteries per unit of energy storage capacity is $\$ 1,400 / \mathrm{kWh}$. In contrast, this figure is only $\$ 88 / \mathrm{kWh}$ for the hydrogen tank, assuming a $45 \%$ conversion efficiency in the fuel cell. In addition, the batteries are replaced after 15 years in service, which further increases their annualized cost. In contrast, the electrolyzer is assumed to last 20 years and the fuel cell 30,000 hours, or about 30 years for the low-penetration systems.

If the batteries are removed from the PV-wind-fuel cell-battery configuration (as in the PV-windfuel cell configuration), the fuel cell capacity doubles from $.2 \mathrm{~kW}$ to $.4 \mathrm{~kW}$. This occurs because the batteries are useful for providing large amounts of power for short time periods, enabling a smaller, less expensive fuel cell in the PV-wind-fuel cell-battery configuration. 
The configuration rankings listed in TABLE 2 change significantly as a function of wind speed, fuel cell cost, and electrolyzer cost. The optimal system type (OST) graph in FIGURE 2 is a useful tool for viewing the sensitivity of the optimal system type to these parameters. Along the $\mathrm{x}$-axis is the annual mean wind speed at the site at $10-\mathrm{m}$ elevation. Along the y-axis is the capital cost multiplier for the fuel cell and electrolyzer. The capital cost multiplier is used to study the effect of changes in component cost. For example, the baseline system assumes a capital cost of $\$ 5,000 / \mathrm{kW}$ for the fuel cell and $\$ 3,500$ for the electrolyzer, for a combined cost of $\$ 8,500 / \mathrm{kW}$. A capital cost multiplier of . 1 corresponds to a combined capital cost of $\$ 850 / \mathrm{kW}$ for the fuel cell and electrolyzer. Superimposed on the graph at 60 points is the levelized COE. HOMER performed simulations of every possible configuration at each of these points. The optimal system type plot is interpolated from the results at each of these points.

Fuel cells are present in each configuration in FIGURE 2, indicating that they are economically competitive today at the radio repeater station given the assumptions of this study. Furthermore, batteries cannot compete with fuel cells in some instances when fuel cell and electrolyzer costs are below $30 \%$ of their present value.

In winds between $4.25 \mathrm{~m} / \mathrm{s}$ and $7.25 \mathrm{~m} / \mathrm{s}, \mathrm{PV}$ is eliminated from the system. However, the PV system becomes competitive above $7.25 \mathrm{~m} / \mathrm{s}$ at low fuel cell and electrolyzer costs. This is a result of the limited modularity of the wind turbines. The two PV systems in the lower right corner are able to use only one 400-W SW AIR turbine with a small amount of PV, rather than the one relatively large 1-kW Bergey turbine required by the other systems.

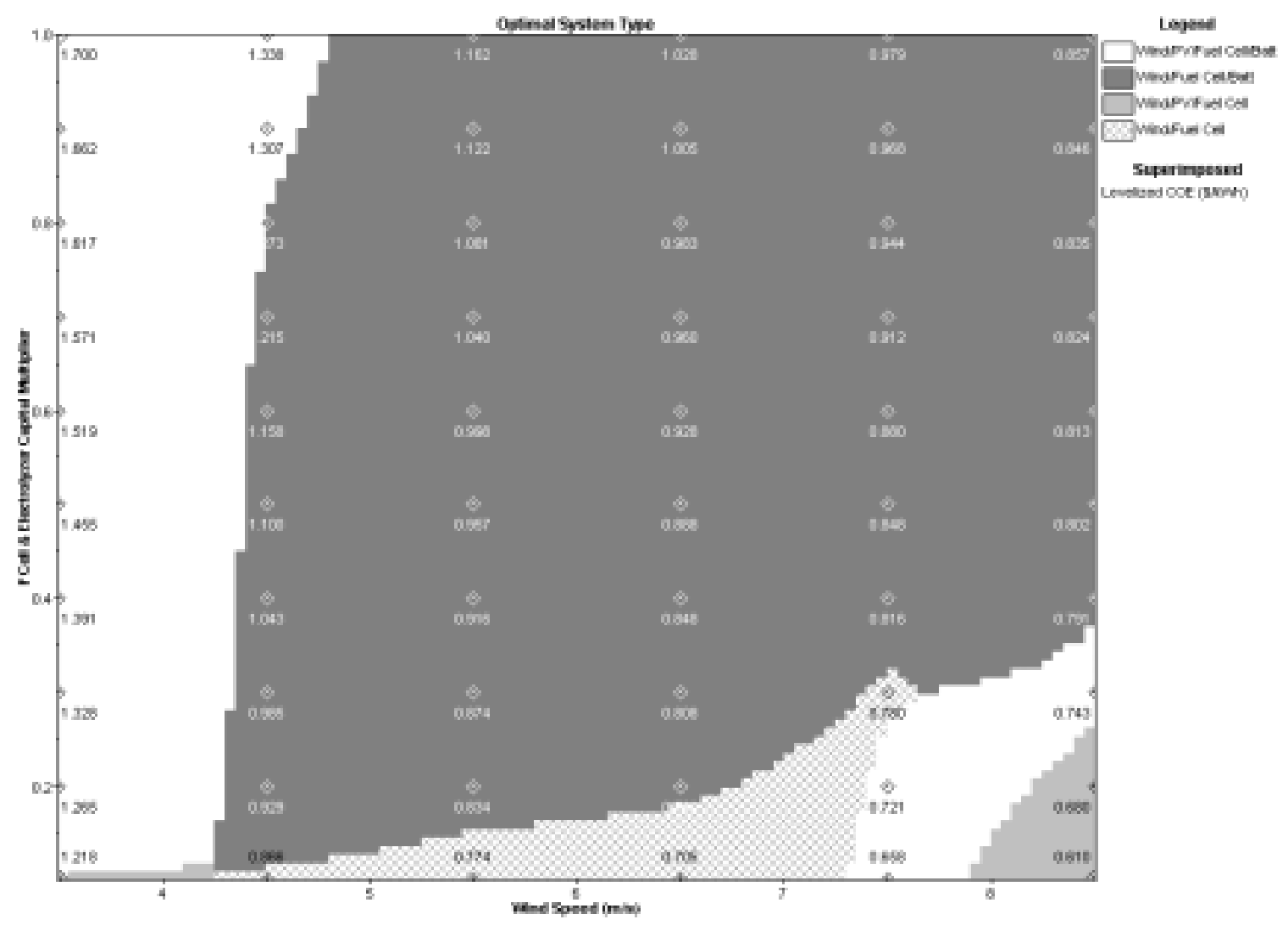

FIGURE 2: OPTIMAL SYSTEM TYPE (WITH COE SUPERIMPOSED) AS A FUNCTION OF ELECTROLYZER AND FUEL CELL CAPITAL COSTS AND MEAN ANNUAL WIND SPEED. 


\section{Effects of Using Lead Acid Batteries}

A critique of this study revealed that using NiCad batteries in the radio repeater analysis is a relatively poor assumption because these batteries are very expensive compared to lead acid batteries. This critique was obtained too late to affect the original publication of results ${ }^{15}$; however, the simulation has since been repeated substituting inexpensive Trojan T-105 lead acid batteries for the NiCad batteries. All HOMER inputs remained the same for this simulation except for the change in batteries and a slight reduction in the size of the search space in order to speed processing time.

$\mathrm{T}-105$ batteries are similar to automobile batteries. They represent the other end of possible battery choices in that they are inexpensive, require more maintenance (maintaining the electrolyte level), and have a significantly shorter life. These batteries cost roughly $\$ 60$ each. At $6 \mathrm{~V}$ each and 225 Ah capacity, they cost only $\$ 44 / \mathrm{kWh}$, which is nearly half the present cost of hydrogen storage.

The results in TABLE 3 for the nominal wind speed and nominal capital cost multipliers illustrate that the fuel cells are much less competitive when considering lead acid batteries. The cost of energy for systems using fuel cells (PV WT FC and PV FC) is more than double that of the least cost system (PV Bat).

TABLE 3: LEAST-COST SOLUTION IN EACH CATEGORY FOR THE RADIO REPEATER STUDY USING LEAD ACID BATTERIES (3.49 M/S MEAN WIND SPEED; ELECTROLYZER AND FUEL CELL CAPITAL COST MULTIPLIERS $=1.0)$

\begin{tabular}{|c|c|c|c|c|c|c|c|c|c|c|}
\hline \multirow[b]{2}{*}{ Category } & \multicolumn{6}{|c|}{ Configuration } & \multicolumn{4}{|c|}{ Performance } \\
\hline & $\begin{array}{l}\text { PV } \\
\text { kW }\end{array}$ & $\begin{array}{c}\text { Turbine } \\
\text { kW }\end{array}$ & $\begin{array}{r}\text { uel C } \\
\text { kW }\end{array}$ & $\begin{array}{l}\text { Batts E } \\
\text { Ea. }\end{array}$ & $\begin{array}{r}\text { lectrol } \\
\mathrm{KW} \\
\end{array}$ & $\begin{array}{l}\text { Store } \\
\text { kg }\end{array}$ & Tot & $\begin{array}{l}\text { tal Cap. } \\
\$\end{array}$ & $\begin{array}{c}\text { COE } \\
\$ / k W h\end{array}$ & $\begin{array}{l}\text { FC } \\
\text { hrs }\end{array}$ \\
\hline PV Bat & 0.40 & - & - & 7 & - & - & $\$$ & 3,620 & 0.78 & - \\
\hline PV WT Bat & 0.20 & 0.4 & - & 13 & - & - & $\$$ & 3,629 & 0.82 & - \\
\hline WT Batt & - & 0.8 & - & 70 & - & - & $\$$ & 6,698 & 1.83 & - \\
\hline PV WT FC & 0.40 & 0.8 & 0.40 & - & 0.30 & 1.0 & $\$$ & 10,068 & 2.34 & 3,581 \\
\hline PV FC & 0.80 & - & 0.40 & - & 0.40 & 0.8 & $\$$ & 10,790 & 2.70 & 4,956 \\
\hline
\end{tabular}

The OST plot in FIGURE 3 is significantly different from that derived when using $\mathrm{NiCaD}$ batteries. The fuel cell is only competitive in select instances below a capital cost multiplier of .3. In these instances, the hydrogen system is used to reduce the number of batteries by $22 \%$ to $40 \%$. However, these configurations only have a marginal economic advantage, which is smaller than the uncertainty of this study. As a result, the equivalent systems without fuel cells would likely be used instead because they are much less complex. 


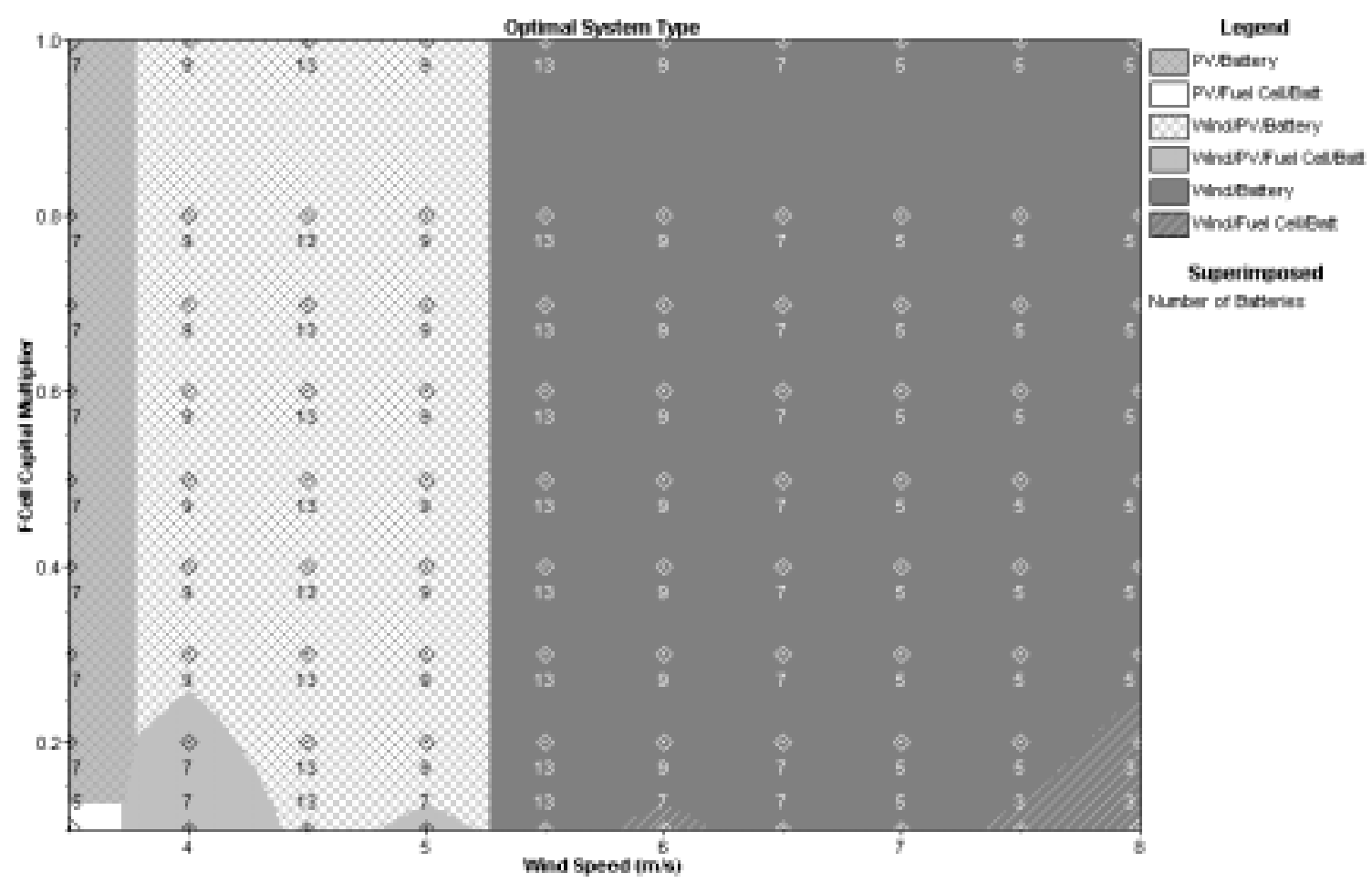

FIGURE 3: OPTIMAL SYSTEM TYPE (WITH NUMBER OF BATTERIES SUPERIMPOSED) AS A FUNCTION OF ELECTROLYZER AND FUEL CELL CAPITAL COSTS AND MEAN ANNUAL WIND SPEED.

\section{Wales, Alaska Analysis}

\section{System Description}

In 1995, NREL and the Kotzebue Electric Association of Kotzebue, Alaska, began a collaboration to reduce the cost of electricity for Wales (a northwest Alaska village with a population of about 160) by implementing a wind-diesel-battery hybrid power system. Wales now uses two $50-\mathrm{kW}$ wind turbines (plans are underway to install a third turbine) and a battery bank to supplement diesel generators. This study considers the option of adding hydrogen storage and generators to the existing hybrid system.

\section{Operating Principle}

FIGURE 4 depicts a schematic of the Wales hybrid system with an electrolyzer, a fuel cell, and hydrogen storage added to the system. The theory of operation for this system is to use the wind turbine supplemented by the batteries or fuel cell to meet the load (with the diesel off) whenever possible. HOMER decides whether to use energy from the battery, fuel cell, or both based on the replacement cost and O\&M of the devices. In this simulation, HOMER used the full extent of the fuel cell capacity for this system before using the batteries. When excess wind energy is available, power is routed first to the batteries (in a load following strategy), then to the electrolyzer, and finally to the thermal load, thereby saving heating fuel as well as diesel fuel for electric generation. 


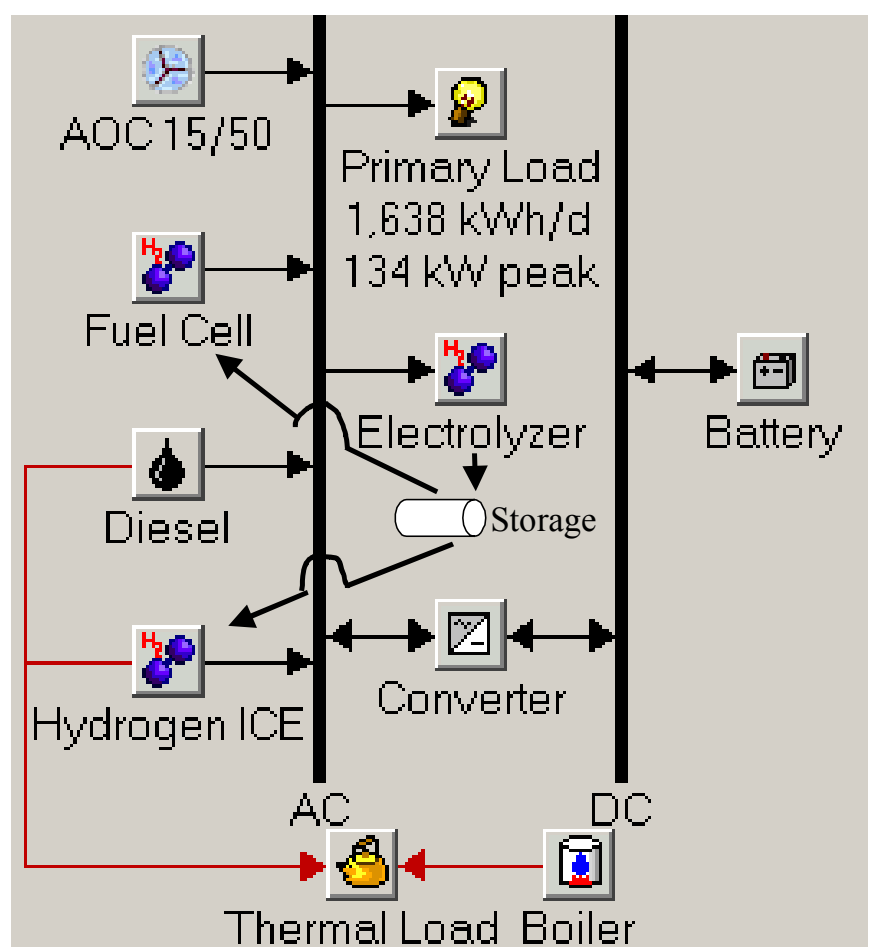

\section{FIGURE 4: SCHEMATIC OF THE LOW-HYDROGEN-PENETRATION SYSTEM IN WALES (HYDROGEN STORAGE NOT SHOWN).}

\section{Load}

Electric load data averaged every 15 minutes were available for Wales from November 1993 through October $1994^{16}$. These data were converted to hourly data for input to HOMER. The village has an annual average load of $1,638 \mathrm{kWh} / \mathrm{d}$, with a peak load of $134 \mathrm{~kW}$. The daily and hourly noise averages $8.5 \%$.

Loads to heat the powerhouse and the school were also included in the model using the following estimates for the powerhouse and school respectively: $60 \mathrm{~kW}$ and $50 \mathrm{~kW}$ in the winter; $40 \mathrm{~kW}$ and $30 \mathrm{~kW}$ in the spring; $20 \mathrm{~kW}$ and $20 \mathrm{~kW}$ in the summer; and $40 \mathrm{~kW}$ and $30 \mathrm{~kW}$ in the fall. This thermal load had to be simplified by combining the powerhouse and school into one load because HOMER only allows one thermal load. This differs from the actual system because the boiler and wind turbine serve only the school thermal load, and the diesel serves only the powerhouse.

\section{Resources}

Wales has a poor solar resource. For this reason, PV was not considered as a reasonable alternative for this scenario. Solar radiation and clearness data were obtained from nearby Nome; the annual average global radiation is $2.45 \mathrm{kWh} / \mathrm{m}^{2} /$ day, with an annual average clearness index of 0.337 .

Wind data were derived from a 15 -minute time series ${ }^{17}$. The village is in a Class 7 wind regime, with an average wind speed of $8.7 \mathrm{~m} / \mathrm{s}$ and Weibull-k value of 2.25 .

\section{Hydrogen Components}

The cost and assumptions for the hydrogen system (electrolyzer, water, and fuel cell) are the 
same as in the radio repeater analysis with a few exceptions. The fuel cell capital cost was reduced from $\$ 5,000 / \mathrm{kW}$ to $\$ 3,000 / \mathrm{kW}$ to account for the larger scale (roughly 2 orders of magnitude) of the Wales system. Likewise, the electrolyzer cost was reduced from $\$ 3,500$ to $\$ 2,000$.

Also considered in this study was the use of a hydrogen ICE to supplement or replace the fuel cell. Ballard Power Systems and Ford Power Products are developing a 114-kVA hydrogen genset based on a standard 6.8L Ford production engine. A preliminary specification sheet for the Ecostar product indicates electrical efficiency near rated power of nearly $30 \%$. This study assumes the O\&M cost of the hydrogen ICE to be the same as the diesel system $(\$ 5 / \mathrm{hr})$ and assumes the capital cost of the genset is $\$ 500 / \mathrm{kW}$.

O\&M was also considered for the fuel cell and electrolyzer in this analysis. For the fuel cell, the O\&M was assumed to cost $1 / 10$ that of a diesel, or $\$ .0033 /$ hour $/ \mathrm{kW}$. The O\&M for the electrolyzer system is estimated to be $7 \%$ of the annual capital cost per year, or $\$ 245 / \mathrm{yr}$. The cost of the water treatment is included in this figure.

\section{Wind Turbines}

The wind turbines used in Wales are made by Atlantic Orient Corporation and are rated by the manufacturer at $50 \mathrm{~kW}$ in $12 \mathrm{~m} / \mathrm{s}$ winds. Although the turbine output has been higher than projected by the power curve in the extremely cold temperatures and increased air density of Kotzebue winters, this effect was not modeled in this study. The installed turbine cost is estimated at $\$ 110,000$ (includes $\$ 45,000$ for shipping and installation) with O\&M costs estimated at $\$ 2,682 / \mathrm{yr}$ (approximately $\$ .015 / \mathrm{kWh})^{18}$. Lifetimes are assumed to be 20 years.

\section{Rotary Converter}

For the remote village scenario, a rotary converter, rather than an inverter, is used at the site because of the maintenance capabilities of local crews. The rotary converter is used to convert the battery power to alternating current, provide reactive power to the system, and allow all diesels to be shut down. A $100-\mathrm{kW}$ rotary converter is estimated to cost an additional $\$ 30,000$ beyond a system that uses a synchronous condenser to perform the latter two functions above. The maintenance of the converter is estimated at $\$ 500 / \mathrm{yr}$.

\section{Batteries}

The batteries in the Wales system consist of 200 Saft SPH130 NiCad batteries, resulting in a $130 \mathrm{Ah}, 240 \mathrm{~V}$ NiCad bank, for a nominal capacity of $31.2 \mathrm{kWh}$. The cost of this bank is estimated at $\$ 43,500(\$ 1,400 / \mathrm{kWh})$. The battery charging is limited to a $2 \mathrm{C}(260 \mathrm{~A})$ charge rate limit $^{19}$. The O\&M is estimated to cost $\$ 200 /$ year.

\section{Diesel Generator Sets}

The costs for new diesel generators are well established and range from $\$ 250-\$ 500$ per $\mathrm{kW}$ of rated capacity ${ }^{20}$. A lower value of $\$ 200 / \mathrm{kW}$ was used based on a survey of modern diesel units. Diesel generator sets require a significant amount of labor and materials to maintain proper operation. Costs for regular maintenance can be high depending on maintenance schedules; for the small village scenario, a cost of $\$ 5$ per hour of operation was used $(\$ .033 / \mathrm{hr} / \mathrm{kW})$, with an operating lifetime of 10,000 hours $^{21}$.

Some of the waste heat from the diesel is used to heat the school and the plant. A water jacket in the diesel captures this heat. However, the energy in the stack gasses is lost. A common approximation for the dissipation of the energy in the fuel is one-third to electricity, one-third to 
the water jacket, one-third to the exhaust gasses. In line with this approximation, this study assumed that the energy in the water jacket energy ( $50 \%$ of the total waste energy) could be used to meet the thermal load.

\section{Diesel Fuel}

Diesel fuel prices vary widely. Villages such as Wales buy large quantities (waterways are iced over much of the year) and can get reasonable prices such as $\$ 1.28 /$ gal $(\$ .33 / \mathrm{L})$ delivered $^{22}$. Costs for storage, tank replacement, and spill clean-up were not considered.

\section{Balance of System (BOS)}

BOS costs include miscellaneous costs that can't be ascribed to one particular component but are associated with the system as a whole. Examples include road construction, site preparation, system controllers, equipment housing, etc. Available data were used. This study used a BOS cost of $\$ 38,000$ with a fixed system capital cost of $\$ 138,000$.

\section{Optimization}

The focus of the Wales analysis is on low-hydrogen-penetration wind diesel systems, or systems in which a relatively small hydrogen component is used to supplement the wind turbine and diesel system. Another possible system configuration is to use a high-hydrogen-penetration system similar to the radio repeater or a system that relies primarily on the wind turbines and fuel cell to provide the village power with diesel as a possible back-up power source. To limit the simulation time to a reasonable figure, separate simulations were performed to examine the feasibility of low- and high-hydrogen-penetration systems.

For the final low-hydrogen-penetration simulation, HOMER examined 313,362 possible solutions by the combining components listed in TABLE 4 . In addition, roughly eight sensitivity studies were performed in the final analysis, each of which requires HOMER to repeat the simulation. This took more than 14 hours using a 2-GHz personal computer.

The components of the high-penetration system are identical to the low-hydrogen-penetration system except that $50 \%$ of the fuel cell waste heat is routed to the thermal load, which increases the overall efficiency of the fuel cell to about $63 \%$. This change was made because the optimum fuel cells are significantly larger in high-penetration systems, making heat recovery more worthwhile. The search space considered for the high-penetration simulations is similar in size as for the low-hydrogen-penetration system except that the diesel size was varied and larger electrolyzers, fuel cells, and hydrogen storage capacities were considered.

TABLE 4: OPTIMIZATION SEARCH SPACE USED FOR THE WALES LOW-HYDROGENPENETRATION ANALYSIS

\begin{tabular}{|c|c|c|c|c|c|c|c|}
\hline$A O C 15 / 50$ & Fuilcellam & Diesied (KW) & Hydroces ICE (XW) & Basary & Convete [WW & Electohpar (6.W) & H2 Tark k ab \\
\hline 0 & 0.001 & 149000 & 0.160 & D & 0.003 & 0.000 & D.0נ0 \\
\hline 2 & 1.001 & & 25100 & 100 & 100.003 & 3100 & 2010 \\
\hline 3 & 6001 & & colto & 230 & & 6500 & 6000 \\
\hline 4 & 1000 & & 75100 & 320 & & $10<00$ & 10030 \\
\hline & 21001 & & 100.100 & 430 & & 20.100 & 20.030 \\
\hline & 31001 & & & 500 & & 30.100 & 30.030 \\
\hline & 41.001 & & & 610 & & $\cos 00$ & 40030 \\
\hline & 51000 & & & & & & \\
\hline & 75001 & & & & & & \\
\hline & 101001 & & & & & & \\
\hline
\end{tabular}




\section{Wales Results}

TABLE 5 lists results from the low-hydrogen-penetration and the high-hydrogen-penetration simulations. The low-hydrogen-penetration simulation resulted in 16 categories, seven of which are listed in TABLE 5 (between the configurations in the first and last rows). Nine of these categories are not shown because they are categories in which HOMER identified a feasible combination of components containing a fuel cell or ICE but one of the components was not run because it was more cost effective to not use it.

The results in TABLE 5 assume present-day prices for the components except for the first and last rows. The first row assumes a fuel cell price one-tenth $(\$ 300 / \mathrm{kW})$ of the present cost. This row is intended to demonstrate the potential of fuel cell systems if fuel cell costs are drastically reduced.

The high-hydrogen-penetration system resulted in two additional categories that are not present in the low-hydrogen-penetration results - the wind-fuel cell and the wind-fuel cell-battery configurations. These categories are unique in that they do not use a diesel generator. The most competitive of these two systems (wind-fuel cell) is included in TABLE 5 in the last row. This result was obtained using a fuel cell price of $\$ 300 / \mathrm{kW}$ and an electrolyzer price one-tenth $(\$ 200)$ of the cost today. This result is intended to demonstrate the infeasibility of high-hydrogenpenetration systems even at extremely favorable fuel cell and electrolyzer costs.

FIGURE 5 and FIGURE 6 plot the capital cost and COE for each system normalized by the leastcost, present-day system (wind-diesel-battery). From these plots, it is immediately apparent that the wind turbine-fuel cell system (high-hydrogen-penetration) is not cost competitive, even when both the electrolyzer and fuel cell are assumed to cost one-tenth of their current capital cost.

Although the capital costs of each system are significantly higher than a diesel-only system, the low-penetration systems have COEs below that of the diesel-only system. This is a result of the significant maintenance and fuel cost for the diesels and the relatively good wind resource.

For low-hydrogen-penetration systems, the competitiveness of a wind-diesel-fuel cell system depends primarily on the cost of the fuel cell and is relatively insensitive to the electrolyzer cost or hydrogen storage cost. This is due in part to the fact that the optimal wind-diesel-fuel cell system uses a small electrolyzer and small amount of hydrogen storage. In addition, the electrolyzers cost $33 \%$ less per $\mathrm{kW}$ than fuel cells (see FIGURE 7 for the relative life cycle costs of the system components).

TABLE 5 indicates that the least-cost system today is a diesel-wind-battery system. The next two most competitive systems add a fuel cell or ICE and an electrolyzer to this system. The addition of a small hydrogen system to these components reduces the battery bank size by $20 \%$. However, the relatively small size of these components and the relatively small number of hours these components are used indicate that the primary benefit for the system is from the batteries.

In the next two systems (D WT FC and D WT ICE), the batteries are replaced with a fuel cell or ICE. In the fuel cell system, a very small electrolyzer $(3 \mathrm{~kW})$ and hydrogen storage tank $(3 \mathrm{~kg}$, which can provide about $50 \mathrm{kWh}$ of electricity) are used with a moderately sized fuel cell $(30 \mathrm{~kW})$. The hydrogen system in this case is useful for meeting the operating reserve requirement for the wind turbines to shut down the diesels, thereby realizing a significant fuel savings. However, the increased capital cost and higher COE indicate that these systems are not currently competitive with the diesel-wind-battery system under the given assumptions. Furthermore, this study does 
not address whether these configurations will work without a small number of batteries or a super capacitor because of the ramp-up time required for fuel cells.

It is often perceived that the lower capital cost of an ICE engine compared to a fuel cell will make the ICE engine preferable. However, the results of this study indicate that for this system, a fuel cell is currently the most competitive option. This is due to the high O\&M costs for the ICE and the poor efficiency at partial loads.

The next system is the wind-diesel system. This system has a significantly higher COE than the wind-diesel-battery system primarily because the diesel runs one-third more hours and an additional wind turbine is used. These characteristics are due in part to the $50 \%$ operating reserve requirement placed on the wind turbines, which the batteries help meet. In addition, the batteries allow the capture of some of the wind energy when the turbine output exceeds the load.

TABLE 5: LEAST-COST SOLUTIONS IN EACH CATEGORY FOR THE WALES ANALYSIS (ASSUMING \$.35/L DIESEL WITH ELECTROLYZER AND FUEL CELL CAPITAL MULTIPLIERS = 1)

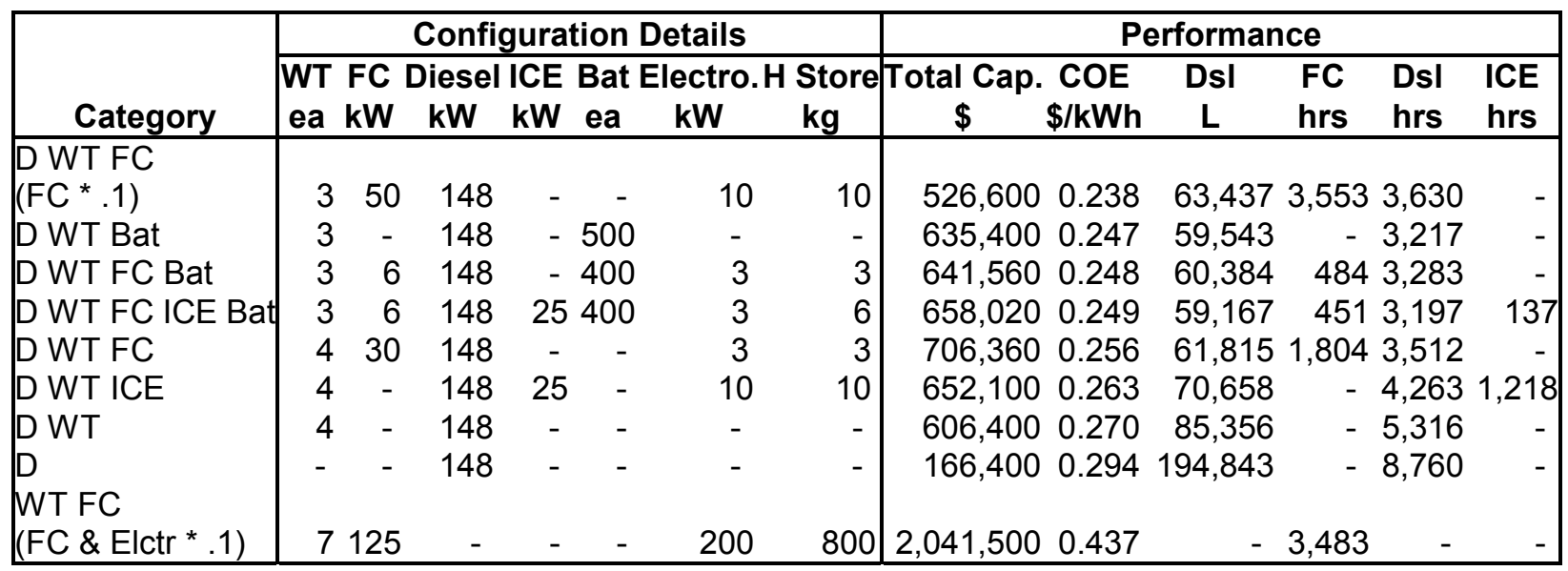

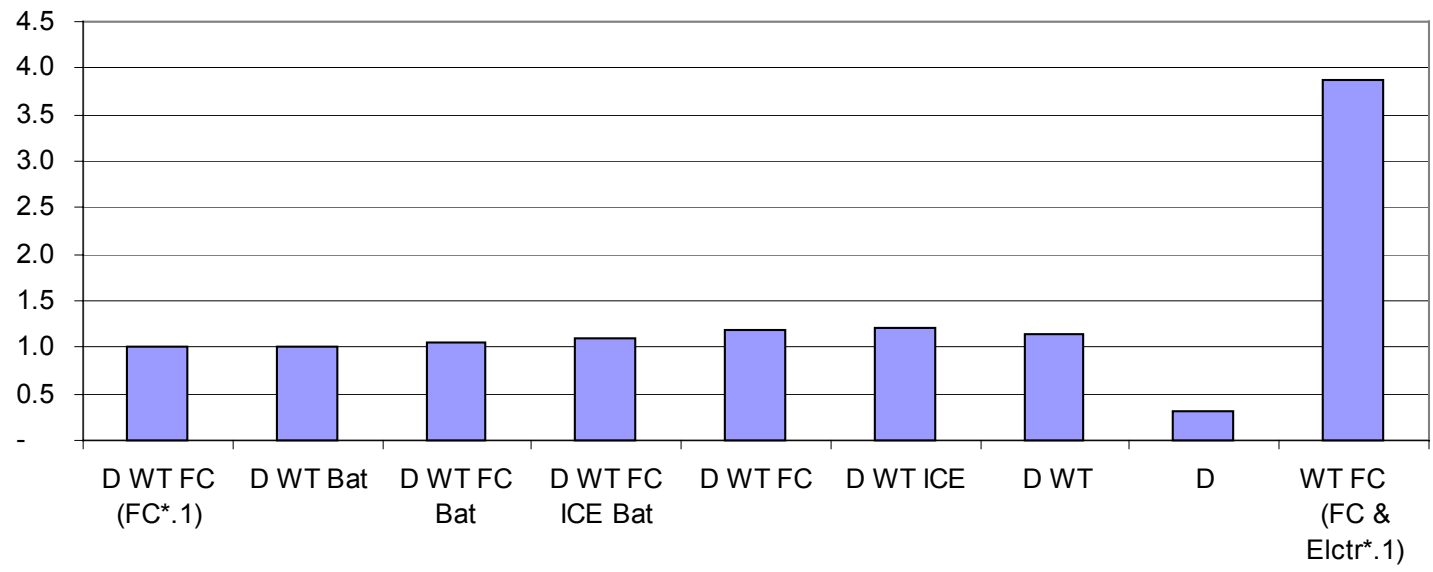

FIGURE 5: TOTAL CAPITAL COSTS FOR EACH SYSTEM RELATIVE TO THE DIESEL-WINDBATTERY SYSTEM. 


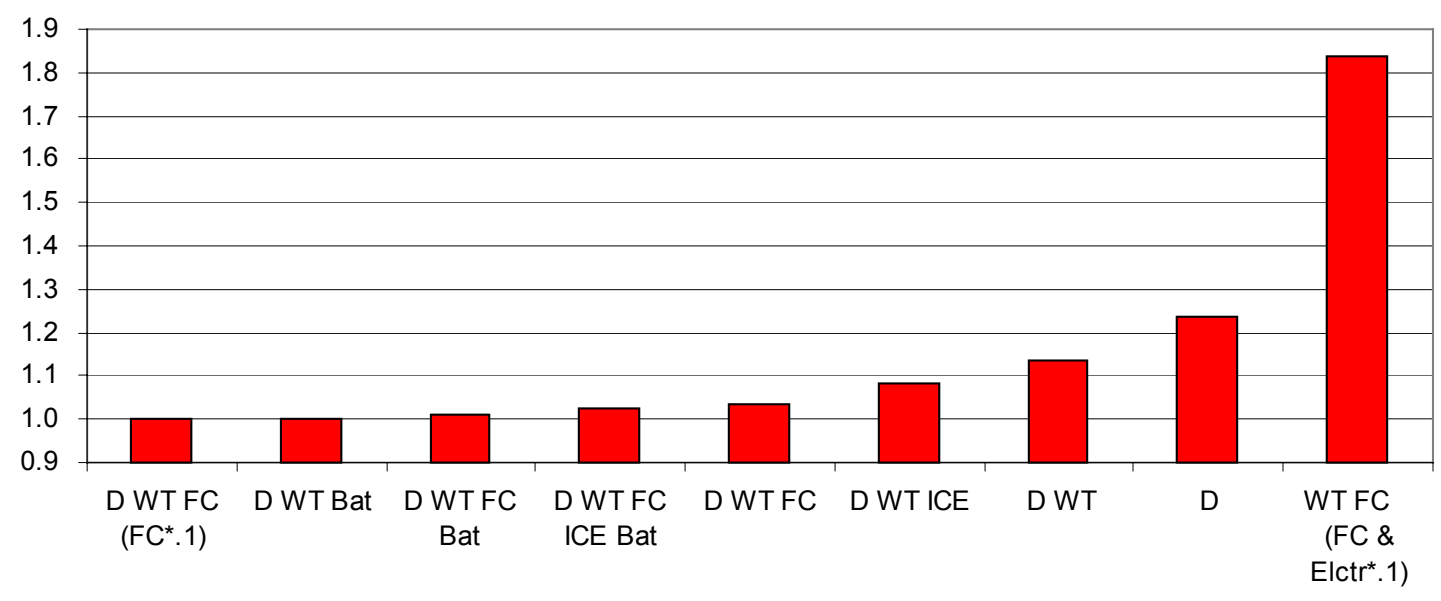

FIGURE 6: COST OF ENERGY FOR EACH SYSTEM RELATIVE TO THE DIESEL-WIND-BATTERY SYSTEM.

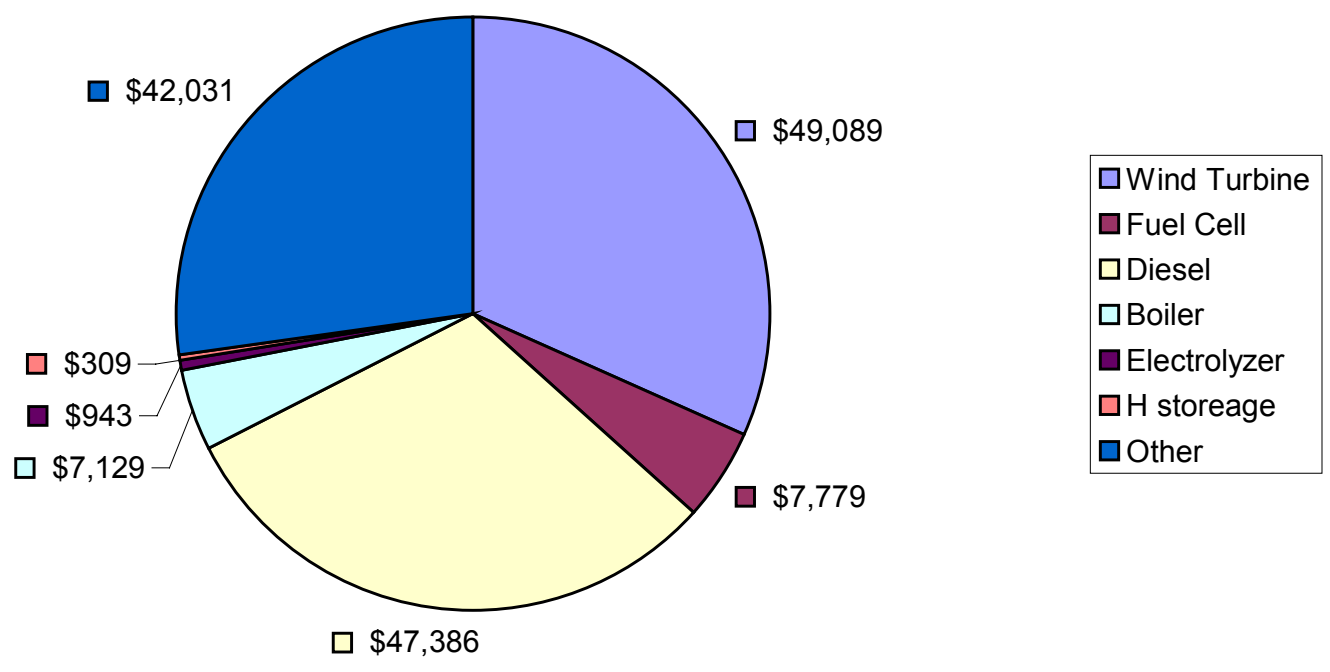

FIGURE 7: TOTAL ANNUALIZED COST FOR THE WIND-DIESEL-FUEL CELL SYSTEM.

It was initially anticipated that the competitiveness of the fuel cell would depend greatly on the cost of diesel. However, FIGURE 8 indicates that the optimal system has only a small dependence on the cost of diesel. This is because the real competitor of a fuel cell system is a wind-diesel-battery system, which is already the least-cost solution at current diesel prices in Wales. However, the cost of diesel does significantly affect the system design. For example, the number of wind turbines, number of batteries, fuel cell capacity (and therefore the electrolyzer capacity and hydrogen storage capacity) are very dependent on the cost of diesel. 


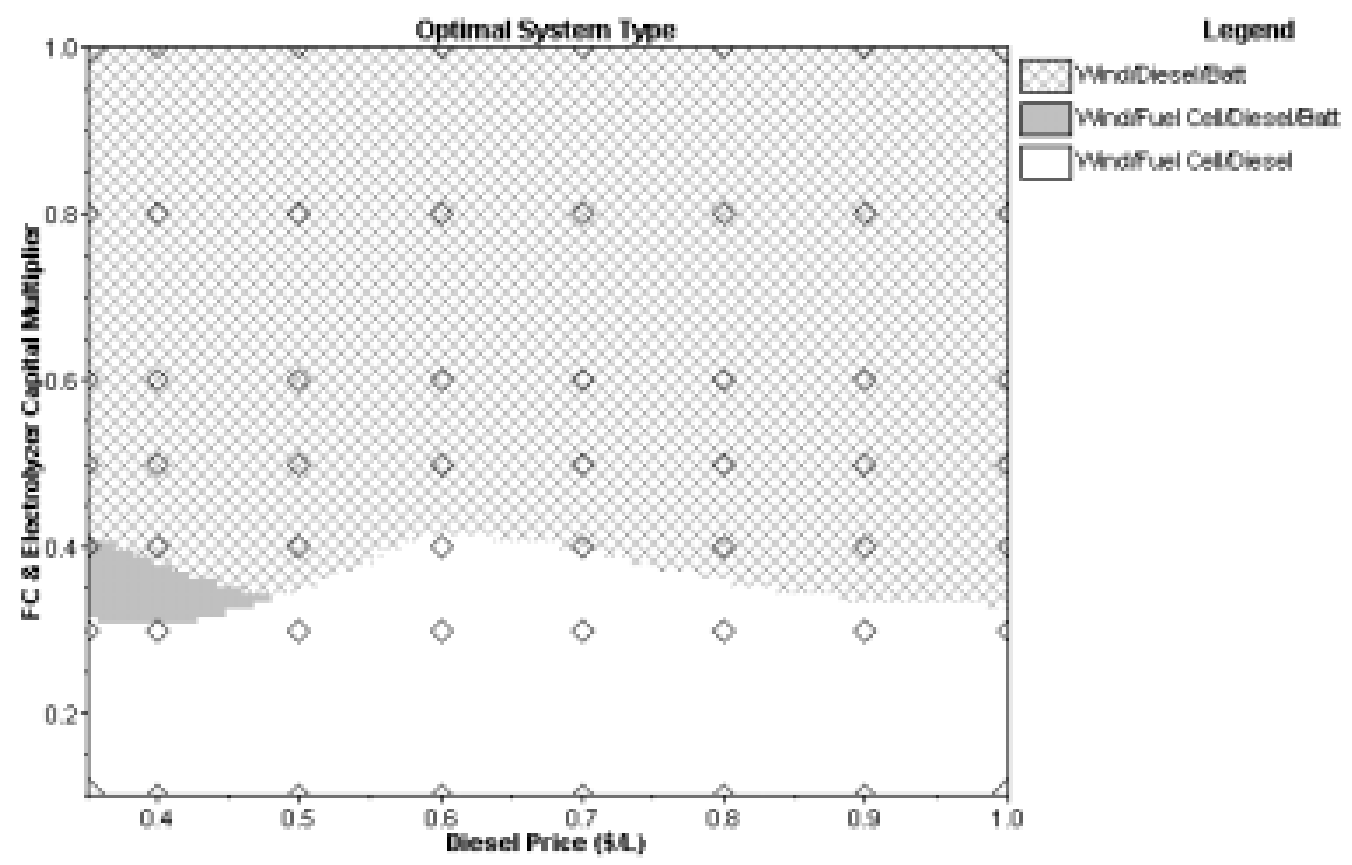

FIGURE 8: OPTIMAL SYSTEM TYPE AS A FUNCTION OF FUEL CELL CAPITAL COSTS AND DIESEL COST FOR WALES LOW-PENETRATION SYSTEMS.

\section{Conclusions}

Depending on the choice of batteries, fuel cells may or may not be economically competitive for systems like the radio repeater. This study considered two extremes of battery technology: inexpensive lead acid batteries and costly NiCad batteries. When using NiCad batteries, the economically optimum configuration for the radio repeater is a PV-wind-fuel cell-battery system. Some of the advantages of adding a fuel cell to the system are long life (relative to batteries) and relatively inexpensive long-term storage. On an economic basis, if fuel cells and electrolyzer costs drop to approximately $30 \%$ of their current values, hydrogen systems could theoretically entirely replace NiCad batteries under many conditions, despite their lower round-trip efficiency and relatively high cost. However, at present prices for fuel cells and electrolyzers, most optimum systems have batteries because their fast discharge rates facilitate smaller fuel cells.

When using inexpensive lead acid batteries, fuel cells and electrolyzer costs need to drop to at least $25 \%$ of their current values to become economically competitive. Even then, the increased complexity of including a hydrogen system will likely favor the choice of systems without hydrogen systems.

For medium-scale remote systems such as Wales, high-hydrogen-penetration systems do not appear feasible. However, low-hydrogen-penetration systems could certainly become competitive in the near future, depending primarily on the fuel cell cost.

Wind-diesel-battery systems result in the least COE for the Wales system. Replacing the fuel cell with batteries will become economically competitive when fuel cell prices drop $40 \%$ (to 
$\$ 1,200 / \mathrm{kW})$. PEM fuel cells will likely reach this price point, considering installed stationary fuel cell targets are $\$ 400 / \mathrm{kW}$ by 2010 . Thus, fuel cells could be economically competitive in systems like the Wales system by 2010 .

The assumptions of component size, cost, and type (such as battery type) can have a dramatic effect on the optimal system type. The results in this report probably cannot be extrapolated to other renewable energy systems. Other systems should be analyzed on a case-by-case basis.

\section{Future Work}

Detailed modeling and hardware testing are required to determine whether the economically optimum systems identified by HOMER are technically viable. In addition, O\&M should be considered for the radio repeater system. At this time, no plans have been made by the authors to perform these efforts.

\section{Acknowledgements}

This study would not have been possible without timely support from Tom Lambert at Mistaya Engineering Inc. and Peter Lilienthal at NREL. In addition, Tony Jimenez provided valuable guidance and data. Steve Drouilhet at Sustainable Automation, LLC and Mari Shirazi at NREL provided invaluable data and expertise on the current Wales system and on this report.

\section{References}

\footnotetext{
${ }^{1}$ Drouilhet, S.; Shirazi, M. Wales, Alaska High-Penetration Wind-Diesel Hybrid Power System: Theory of Operation. NREL/TP-500-31755. Golden, CO: National Renewable Energy Laboratory, May 2002.

${ }^{2}$ Stand-Alone Photovoltaic Systems: A Handbook of Recommended Design Practices, SAND877023. Albuquerque, NM: Photovoltaic Design Assistance Center, Sandia National Laboratories, March, 1995; pp. 161-173.

${ }^{3}$ Green, J. Internal communication of the 1992 Pendleton, OR wind data file, National Renewable Energy Laboratory, Golden, CO, June 2002.

4 "A Quick Guide to Solar Electricity." National Renewable Energy Laboratory, BR-520-27951, http://www.nrel.gov/ncpv/pdfs/27951.pdf, June 2000, Last accessed April 27, 2003.

${ }^{5}$ Friedland, R.J.; Speranza, J. Hydrogen Production through Electrolysis: Proceedings of the 2001 DOE Hydrogen Program Review. NREL/CP-570-30535. Work performed by Proton Energy Systems, Wallingford, CT. Golden, CO: National Renewable Energy Laboratory, May 2001.

${ }^{6}$ Ogden, J. M. "Prospects for Building a Hydrogen Energy Infrastructure," Annual Review of Energy and the Environment; v24, 1999; pp. 227-279.

${ }^{7}$ Amos, W.A. Costs of Storing and Transporting Hydrogen. NREL/TP-570-25106, Golden, CO: National Renewable Energy Laboratory, November 1998.

${ }^{8}$ Sirosh, R., e-mail communication. Quantum Technologies, July 11, 2002.

${ }^{9}$ UTC Fuel Cells. "Frequently Asked Questions."

http://www.utcfuelcells.com/commercial/faq.shtml. Last accessed April 27, 2003.
} 
${ }^{10}$ Coleman PowerMate, “Airgen Fuel Cell Generator.” http://www.airgen.com/airgen.shtml. Last accessed April 27, 2003.

${ }^{11}$ Fuel Cells 2000, "How Much Do Fuel Cells Cost?" http://www.fuelcells.org/fcfaqs.htm\#cost , Last accessed April 27, 2003.

${ }^{12}$ Fuel Cell Report to Congress. ESECS EE-1973. February 2003; pp. 24, 41.

${ }^{13}$ Fuel Cells 2000, "If all those fuel cell cars are emitting water, won't that create other problems?" http://www.fuelcells.org/fcfaqs.htm\#cost, Last accessed April 27, 2003.

${ }^{14}$ Stand-Alone Photovoltaic Systems: A Handbook of Recommended Design Practices, Albuquerque, NM: Photovoltaic Design Assistance Center, Sandia National Laboratories, SAND87-7023, March 1995, pp. 161-173.

${ }^{15}$ Cotrell, J.; Pratt, J. "Modeling the Feasibility of Using Fuel Cells and Hydrogen Internal Combustion Engines In Remote Renewable Energy Systems." WINDPOWER 2003 Conference and Exposition. May 18-May 21, 2003, Austin, TX. NREL/CP-500-34043. Golden, CO: National Renewable Energy Laboratory, 2003.

${ }^{16}$ Shirazi, M. Internal communication of 15-minute electrical load and wind data for Wales, Alaska. National Renewable Energy Laboratory, Golden, CO, July 5, 2002.

${ }^{17}$ Ibid.

${ }^{18}$ Drouilhet, S.; Shirazi, M. Performance and Economic Analysis of the Addition of Wind Power to the Diesel Electric Generating Plant at Wales, Alaska. National Renewable Energy

Laboratory, September 1997 (was not published).

${ }^{19}$ Ibid.

${ }^{20}$ Elliot, G.; Hunter, R. Wind-Diesel Systems, Cambridge: Cambridge University Press, 1994; p. 223.

${ }^{21}$ Drouilhet, S.; Shirazi, M. Performance and Economic Analysis of the Addition of Wind Power to the Diesel Electric Generating Plant at Wales, Alaska. National Renewable Energy Laboratory, September 1997 (was not published).

${ }^{22}$ Thompson, C. E-mail communication. Thompson Engineering Company, Anchorage, AK. September 12, 2002. 


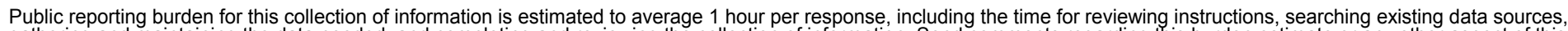

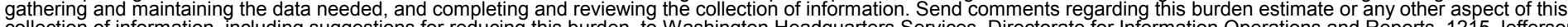
Davis Highway, Suite 1204, Arlington, VA 22202-4302, and to the Office of Management and Budget, Paperwork Reduction Project (0704-0188), Washington, DC 20503.
1. AGENCY USE ONLY (Leave blank)
2. REPORT DATE
3. REPORT TYPE AND DATES COVERED
September 2003
Technical Report

4. TITLE AND SUBTITLE

Modeling the Feasibility of Using Fuel Cells and Hydrogen Internal Combustion Engines

in Remote Renewable Energy Systems

6. AUTHOR(S)

J. Cotrell, W. Pratt

WER3 3250

7. PERFORMING ORGANIZATION NAME(S) AND ADDRESS(ES)

National Renewable Energy Laboratory

1617 Cole Blvd.

Golden, CO 80401-3393

8. PERFORMING ORGANIZATION REPORT NUMBER

NREL/TP-500-34648

9. SPONSORING/MONITORING AGENCY NAME(S) AND ADDRESS(ES)

10. SPONSORING/MONITORING AGENCY REPORT NUMBER

11. SUPPLEMENTARY NOTES

12a. DISTRIBUTION/AVAILABILITY STATEMENT

National Technical Information Service

12b. DISTRIBUTION CODE

U.S. Department of Commerce

5285 Port Royal Road

Springfield, VA 22161

13. ABSTRACT (Maximum 200 words)

Recent advances in hydrogen fuel cell and internal combustion engine technologies have enabled new energy options for supplying electrical power in remote, off-grid areas. The objective of this investigation is to determine under which conditions wind turbines and PV systems can feasibly power electrolyzers to generate and store hydrogen for remote power generation using fuel cells and internal combustion engines. In this study, the optimization software HOMER is used to analyze a small $356-\mathrm{W}$ radio repeater station and a 148-kW village power system. This study concludes that fuel cell systems appear competitive today at the radio repeater station and appear competitive in the village system if fuel cell prices are reduced to $40 \%$ of their current capital cost.

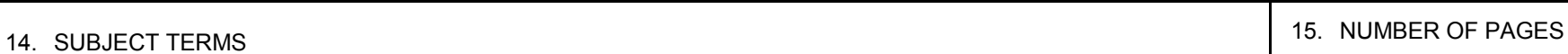

wind energy; wind turbines; fuel cells; hydrogen; hydrogen internal combustion engines; remote renewable energy systems; HOMER

17. SECURITY CLASSIFICATION OF REPORT Unclassified
18. SECURITY CLASSIFICATION OF THIS PAGE Unclassified
19. SECURITY CLASSIFICATION OF ABSTRACT Unclassified
16. PRICE CODE

20. LIMITATION OF ABSTRACT

UL

NSN 7540-01-280-5500

Standard Form 298 (Rev. 2-89) Prescribed by ANSI Std. Z39-18 